\title{
MECHANICAL COMPOSITION OF THE SOILS FORMED ON LIMESTONES AND DOLOMITES IN THE REPUBLIC OF MACEDONIA
}

\author{
Mile Markoski ${ }^{{ }^{*}}$, Tatjana Mitkova ${ }^{1}$, Kole Vasilevski ${ }^{2}$, Zorica Tomić $^{3}$, \\ Marjan Andreevski ${ }^{4}$, Vjekoslav Tanasković ${ }^{1}$ \\ ${ }^{1}$ Faculty of Agriculture Sciences and Food, Ss. Cyril and Methodius University, \\ Skopje, Republic of Macedonia \\ ${ }^{2}$ Faculty of Forestry, Ss. Cyril and Methodius University, Skopje, Republic of Macedonia \\ ${ }^{3}$ Faculty of Agriculture, University of Belgrade, Republic of Serbia \\ ${ }^{4}$ Institute of Agriculture, Ss. Cyril and Methodius University, Skopje, Republic of Macedonia \\ *Corresponding author, e-mail: mmarkoski@zf.ukim.edu.mk
}

\begin{abstract}
The paper presents results from the research of the influence of the parent material on the mechanical composition of calcomelanosols, calcocambisols and terra rossa. The contents of the fine soil separates in the calcomelanosols vary depending on the subtype. The physical sand fraction (coarse sand + fine sand) in the Amo horizon amounts $44.81 \%$ in the organomineral calcomelanosols, $40.13 \%$ in the organogenic and brownised calcomelanosols $36.52 \%$. In the (B)rz horizon in the brownised calcomelanosols it amounts $32.64 \%$. The content of clay + silt or physical clay in the Amo horizon amounts $55.19 \%$ in the organomineral calcomelanosols, $59.87 \%$ in the organogenic and the highest content is in the brownised calcomelanosols $63.48 \%$. The average value of this fraction in the horizon (B)rz in the brownised calcomelanosols amounts $67.36 \%$. In the calcocambisols the average content of the fraction physical sand in the Amo horizon amounts $33.43 \%$, and in the cambic horizon (B)rz $22.50 \%$. In the terra rossa the fraction physical clay is represented with a greater percentage related to the physical sand fraction. In the Amo horizon, in the physical clay fraction, the clay fraction is predominant, average $43.08 \%$, and $52.13 \%$ in the cambic horizon, and $24.90 \%$ in the Amo horizon and $19.37 \%$ in the (B)rz horizon for the silt fraction. From a research soils $36 \%$ of the soils are formed on massive limestone, $13 \%$ are formed on dolomitic limestone and bituminous marbles, $16 \%$ on plate (flat) limestone, $10 \%$ on dolomitic marbles and $12 \%$ on laminated (plate) dolomite and calcite.
\end{abstract}

Key words: mechanical composition; parent material; calcomelanosols; calcocambisols; terra rossa

\section{INTRODUCTION}

The researches on the soils formed on limestones and dolomites, in the world, especially in Central and West Europe, have been taking place for a long period of time. The first soil scientist who has described these soils even before 1896 is one of the founders of the genetic pedology, the renowned Russian soil scientist [1].

The knowledge of the texture of these soils has a great importance, since these soils are formed only on certain substrates (pure and compact limestones and dolomites), where all physical, physical - mechanical, chemical and biological properties greatly depend on the parent material. The mechanical composition of these soils varies extensively and depends on the mechanical composition of the residuum from which the mineral part of the soil is composed, on the character of the limestone and the dolomite (the degree of weathering and silicification), on the deposition of nearby materials (from the higher fields) and on the degree of erosion [2]. It also depends on the processes which take place within these soils during their pedogenesis and evolution, and which cause the texture differentiation.

The results from the researches of [3] indicate that the hard limestones, and to a lesser extent, the dolomites, are the main parent material on which 
terra rossa is formed with the most typical morphological, mechanical and chemical properties.

The mechanical composition of these soils in the Republic of Macedonia was researched earlier by 8 authors in 25 papers from the same locations where this research was done. The results of these studies have data in the monograph [2]. Due to the use of different methods of analysis of the mechanical part in the research of other authors problems arise in the comparison of the mechanical structure, particularly in fine earth of the calcomelanosols. For comparison there were taken surveys on mechanical composition according to international Bmethod and recent research which has used the international A-method.

In the research of the parent rocks on which these soils are formed in the Republic of Macedonia we have used the geological maps and their interpreters [4]. The great influence of the parent material on the mechanical composition can be illustrated with the fact that the same is taken as a criterion in the descriptive statistics. The analysis of the variance is according to soil types, subtypes and horizons in the analysis. This paper also describes the influence of the geological composition on the mechanical composition of the three soil types (calcomelanosols. calcocambisols and terra rossa) [2,3].

\section{MATERIAL AND METHODS}

Field research has been carried out for the soils formed on limestones and dolomites, on various locations on the territory of the Republic of Macedonia. Following the field recognition, loca- tions were selected for digging out of the basic pedological profiles (a total of 52), out of which 34 were calcomelanosols WRB - Rendzic Leptosol [5]. 13 calcocambisols (WRB - Chromic Leptic Luvisol on hard limestones) [5], and 5 profiles of terra rossa WRB - Rhodic Leptic Luvisol on hard limestones [5]. The field research was carried out in accordance with the generally accepted methodology in our country [6]. The mechanical composition of the soil was determined according to the international A-method [7], and the peptization has been carried out with $0.1 \mathrm{M}$ sodium pyrophosphate [8]. The fractioning of the mechanical elements has been performed according to the International Classification, and the classification of the soils in texture classes has been performed according to the American triangle [6]. An analysis of variance (ANOVA) has been made for samples of various sizes, for all analyzed properties in both horizons. The influence of the substrate, the soil type and their interaction on the variability of all examined properties has been determined. The importance of the differences among the mean values of the analyzed properties, has been determined with the Tukey test, for level $p$ $<0.05$, for each parent material and soil type separately. All statistical analyses have been made with the software package R.

\section{RESULTS AND DISCUSSION}

Figure 1 contains an overview of the parent materials on which calcomelanosols, calcocambisols and terra rossa are formed.

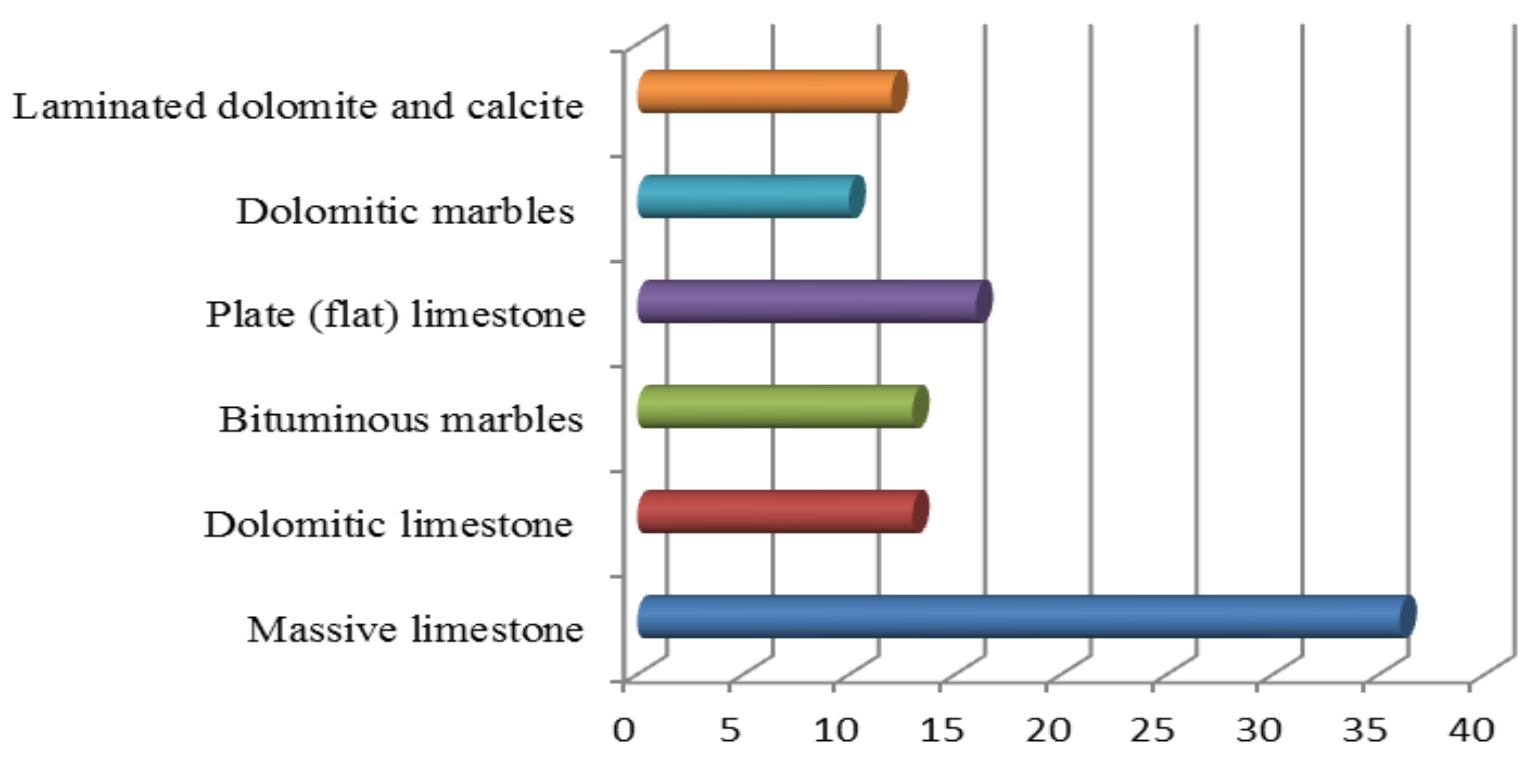

Figure 1. Percentage of parent materials in calcomelanosols, calcocambisols and terra rossa formation 
It can be seen from the chart that $36 \%$ of the researched soils are formed on massive limestone, $13 \%$ are formed on dolomitic limestone and bituminous marbles, $16 \%$ on plate (flat) limestone, $10 \%$ on dolomitic marbles and $12 \%$ on laminated (plate) dolomite and calcite. On the basis of the above, it can be confirmed that the soils are formed from horn slate - hornfels facies, and their composition has an influence on the mechanical composition. This facia has a thickness of around 500-550 $\mathrm{m}$, it is composed of dolomites, plate (flat) limestone with hornfels and massive limestone, and it represents a continuation in Anisian and Ladinian, and it strongly reflects on the morphology, physical and physical-mechanical properties, mineral composition and the chemical properties of the soils.

With the analysis of the mechanical composition of the first soil type in the evolution series of the soils formed on limestones and dolomites, calcomelanosols, the following has been noticed: the content of coarse fragments varies extensively, where the highest percentage is found in humus accumulative horizon Amo, $12.2 \%$ in organogenic and $11.08 \%$ in organomineral calcomelanosols, while in the brownised calcomelanosols it amounts $6.70 \%$. In the cambic horizon (B)rz in brownised calcomelanosols, its mean content amounts $4.39 \%$.

The content of particular fractions of the fine earth of calcomelanosols varies depending on the subtype. In order to have a better understanding, the mean values for each fraction of the fine earth in calcomelanosols, and for each subtype by a horizon separately, are given in Tables 1 and 2. The average content of the coarse sand fraction $(0.2-2 \mathrm{~mm})$ for all examined soil subtypes in the Amo horizon ranges from $2.83 \%$ in organogenic calcomelanosols, $10.28 \%$ in brownised calcomelanosol, up to $10.81 \%$ in organogenic calcomelanosol. Its content in the cambic horizon (B)rz in brownised calcomelanosol amounts $10.47 \%$. In the Amo horizon, the fine sand fraction $(0.02-0.2 \mathrm{~mm})$ the highest mean value is found in organogenic calcomelanosols $37.30 \%$, then in organomineral $34.00 \%$ and brownised calcomelanosols $26.24 \%$. The lowest average content of this fraction is found in cambic horizon (B)rz in brownised calcomelanosols $22.17 \%$. The total contents of these two fractions as physical sand (coarse + fine sand) in the horizon Amo amount $44.81 \%$ in organomineral calcomelanosols, $40.13 \%$ in organogenic and $36.52 \%$ in brownised calcomelanosols. In the (B)rz horizon, in brownised calcomelanosols, it amounts $32.64 \%$. We have noticed that the physical sand (coarse sand + fine sand) appears with more than $50.00 \%$ only in the profiles formed on dolomitic marbles $(53.88 \%)$. In all other profiles of calcomelanosols, this fraction is present with less than $50.00 \%$. In the Amo horizon, the silt fraction $(0.002-0.02 \mathrm{~mm})$ in organogenic calcomelanosol has the highest mean value of $37.60 \%$, and for the other subtypes, the content of this fraction amounts $22.52 \%$ in organomineral calcomelanosols and $26.88 \%$ in brownised calcomelanosols. The silt content in the cambic horizon (B)rz in brownised calcomelanosols amounts $26.33 \%$.

Table 1. Mean values for the mechanical composition of the soils in the horizon Amo

\begin{tabular}{|c|c|c|c|c|c|c|c|c|c|c|c|c|c|c|c|}
\hline \multirow[b]{2}{*}{$\begin{array}{l}\text { Soil } \\
\text { type }\end{array}$} & \multirow[b]{2}{*}{$\mathbf{N}$} & \multicolumn{2}{|c|}{$>2 \mathrm{~mm}$} & \multicolumn{2}{|c|}{$0.2-2 \mathrm{~mm}$} & \multicolumn{2}{|c|}{$0.02-0.2 \mathrm{~mm}$} & \multicolumn{2}{|c|}{$0.02-2 \mathrm{~mm}$} & \multicolumn{2}{|c|}{$0.002-0.02 \mathrm{~mm}$} & \multicolumn{2}{|c|}{$<0.002 \mathrm{~mm}$} & \multicolumn{2}{|c|}{$<0.02 \mathrm{~mm}$} \\
\hline & & $\bar{x} \%$ & SD & $\bar{x} \%$ & SD & $\bar{x} \%$ & SD & $\bar{x} \%$ & SD & $\bar{x} \%$ & SD & $\bar{x} \%$ & SD & $\bar{x} \%$ & SD \\
\hline 1 & 7 & $12.20 \mathrm{~b}$ & 3.05 & 2.83 & 1.80 & 37.30 & 8.07 & $40.13 \mathrm{ab}$ & 8.18 & $37.60 \mathrm{~b}$ & 4.95 & $22.27 \mathrm{a}$ & 7.23 & $59.87 \mathrm{ab}$ & 8.18 \\
\hline 2 & 22 & $11.08 \mathrm{~b}$ & 6.43 & 10.81 & 14.70 & 34.00 & 15.21 & $44.81 b$ & 13.41 & $22.52 \mathrm{a}$ & 9.56 & $32.68 \mathrm{ab}$ & 9.50 & $55.19 \mathrm{a}$ & 13.41 \\
\hline 3 & 5 & $6.70 \mathrm{a}$ & 3.42 & 10.28 & 8.33 & 26.24 & 4.88 & $36.52 \mathrm{ab}$ & 6.33 & $26.88 \mathrm{a}$ & 3.39 & $36.60 \mathrm{ab}$ & 3.89 & $63.48 \mathrm{ab}$ & 6.33 \\
\hline 4 & 13 & $4.82 \mathrm{a}$ & 3.56 & 6.18 & 5.20 & 27.25 & 9.27 & $33.43 \mathrm{ab}$ & 9.96 & $28.38 \mathrm{a}$ & 10.05 & $38.19 b$ & 6.77 & $66.57 \mathrm{ab}$ & 9.96 \\
\hline 5 & 5 & $3.18 \mathrm{a}$ & 1.02 & 8.27 & 5.91 & 23.75 & 8.22 & $32.02 \mathrm{a}$ & 14.00 & $24.90 \mathrm{a}$ & 8.06 & $43.08 \mathrm{~b}$ & 10.40 & $67.98 \mathrm{~b}$ & 14.00 \\
\hline P.M. & $\mathbf{N}$ & $\bar{x} \%$ & SD & $\bar{x} \%$ & SD & $\bar{x} \%$ & SD & $\bar{x} \%$ & SD & $\bar{x} \%$ & SD & $\bar{x} \%$ & SD & $\bar{x} \%$ & SD \\
\hline M.L. & 19 & $5.79 a$ & 3.30 & 6.76 & 6.43 & $28.41 \mathrm{a}$ & 8.79 & $35.17 \mathrm{ab}$ & 9.43 & $27.72 \mathrm{ab}$ & 6.82 & 37.11 & 10.89 & $64.83 \mathrm{ab}$ & 9.43 \\
\hline D.L. & 7 & $6.99 \mathrm{ab}$ & 5.53 & 4.93 & 3.27 & $23.79 \mathrm{a}$ & 7.19 & $28.71 \mathrm{a}$ & 6.43 & $37.76 \mathrm{~b}$ & 6.06 & 33.53 & 8.20 & $71.29 \mathrm{~b}$ & 6.43 \\
\hline B.L. & 7 & $7.59 \mathrm{ab}$ & 4.56 & 4.22 & 1.86 & $33.72 \mathrm{ab}$ & 11.41 & $37.94 \mathrm{ab}$ & 11.37 & $32.86 \mathrm{~b}$ & 8.75 & 29.20 & 12.69 & $62.06 \mathrm{ab}$ & 11.37 \\
\hline P.L. & 8 & $8.48 \mathrm{ab}$ & 2.88 & 12.16 & 4.76 & $30.19 \mathrm{ab}$ & 5.09 & $42.35 \mathrm{ab}$ & 6.45 & $23.84 \mathrm{ab}$ & 4.12 & 33.81 & 4.08 & $57.65 \mathrm{ab}$ & 6.45 \\
\hline D.M. & 5 & $14.52 \mathrm{~b}$ & 4.31 & 4.49 & 3.29 & $49.39 b$ & 15.99 & $53.88 \mathrm{~b}$ & 14.37 & $15.86 \mathrm{a}$ & 8.44 & 30.28 & 8.79 & $46.12 \mathrm{a}$ & 14.37 \\
\hline L.D.C. & 6 & $14.79 b$ & 9.90 & 19.76 & 26.34 & $30.40 \mathrm{ab}$ & 18.73 & $50.16 \mathrm{ab}$ & 14.36 & $15.93 \mathrm{a}$ & 9.38 & 33.92 & 10.75 & 49.84ab & 14.36 \\
\hline
\end{tabular}

* values in each column marked with the same letter don't differ significantly between themselves

1. Calcomelanosols organogenic; 2. Calcomelanosols organomineral; 3. Calcomelanosols brownised; 4. Calcocambisols;

5. Terra rossa; P. M. - Parent material; M. L. - Massive limestone; D. L. - Dolomitic limestone; B. L. - Bituminous limestone;

P. L. - Plate limestone; D. M. - Dolomitic marbles; L. D. C. - laminated (plate) dolomite and calcite 
The average content in the smallest fraction of the fine earth clay $(<0.002 \mathrm{~mm})$, in humus accumulative horizon Amo in organogenic calcomelanosols is present with $22.27 \%$, with $32.68 \%$ in organomineral and with not more than $36.60 \%$ in brownised calcomelanosols. The content of clay is the highest, $41.30 \%$, in the cambic horizon (B)rz, in brownised calcomelanosols. The higher percentage of clay in the horizon (B)rz is a result of the more intensive chemical weathering.

Table 2. Mean values for the mechanical composition of the soils in the horizon (B)rz

\begin{tabular}{|c|c|c|c|c|c|c|c|c|c|c|c|c|c|c|c|}
\hline \multirow{2}{*}{$\begin{array}{l}\text { Soil } \\
\text { type }\end{array}$} & \multirow[b]{2}{*}{$\mathbf{N}$} & \multicolumn{2}{|c|}{$>2 \mathrm{~mm}$} & \multicolumn{2}{|c|}{$0.2-2 \mathrm{~mm}$} & \multicolumn{2}{|c|}{$0.02-0.2 \mathrm{~mm}$} & \multicolumn{2}{|c|}{0.02 - 2 mm } & \multicolumn{2}{|c|}{$0.002-0.02 \mathrm{~mm}$} & \multicolumn{2}{|c|}{$<0.002 \mathrm{~mm}$} & \multicolumn{2}{|c|}{$<0.02 \mathrm{~mm}$} \\
\hline & & $\bar{x} \%$ & SD & $\bar{x} \%$ & SD & $\bar{x} \%$ & SD & $\bar{x} \%$ & SD & $\bar{x} \%$ & SD & $\bar{x} \%$ & SD & $\bar{x} \%$ & SD \\
\hline 3 & 5 & $4.39 \mathrm{~b}$ & 5.24 & 10.47 & 5.57 & 22.17 & 4.92 & 32.64 & 8.29 & $26.33 \mathrm{ab}$ & 6.79 & $41.03 \mathrm{a}$ & 3.11 & 67.36 & 8.29 \\
\hline 4 & 14 & $1.65 \mathrm{a}$ & 2.06 & 5.31 & 4.27 & 16.89 & 5.02 & 22.20 & 7.72 & $31.80 \mathrm{~b}$ & 5.63 & $46.00 \mathrm{ab}$ & 8.10 & 77.80 & 7.72 \\
\hline 5 & 7 & $1.42 \mathrm{a}$ & 0.90 & 9.05 & 5.29 & 19.45 & 4.44 & 28.50 & 9.06 & $19.37 \mathrm{a}$ & 5.49 & $52.13 b$ & 8.71 & 71.50 & 9.06 \\
\hline P.M & $\mathbf{N}$ & $\bar{x} \%$ & SD & $\bar{x} \%$ & SD & $\bar{x} \%$ & SD & $\bar{x} \%$ & SD & $\bar{x} \%$ & SD & $\bar{x} \%$ & SD & $\bar{x} \%$ & SD \\
\hline M.L. & 11 & $1.11 \mathrm{a}$ & 0.84 & 8.89 & 6.63 & 17.68 & 5.57 & 26.56 & 11.52 & $20.54 \mathrm{a}$ & 5.43 & 52.90 & 9.08 & 73.44 & 11.52 \\
\hline D.L. & 4 & $1.03 \mathrm{a}$ & 0.67 & 5.79 & 1.66 & 16.66 & 2.80 & 22.45 & 4.18 & $33.61 \mathrm{ab}$ & 3.08 & 43.94 & 2.64 & 77.55 & 4.18 \\
\hline B.L. & 4 & $0.94 \mathrm{a}$ & 0.71 & 3.50 & 1.24 & 21.28 & 3.70 & 24.78 & 4.88 & $33.90 \mathrm{ab}$ & 5.15 & 41.33 & 2.05 & 75.23 & 4.88 \\
\hline P.L. & 5 & $4.79 b$ & 4.96 & 9.96 & 2.66 & 22.10 & 5.07 & 32.06 & 5.37 & $28.78 \mathrm{ab}$ & 4.80 & 39.16 & 1.41 & 67.94 & 5.37 \\
\hline D.M. & 1 & $8.15 b$ & I & 1.43 & I & 15.17 & I & 16.60 & I & $35.50 \mathrm{ab}$ & I & 47.90 & / & 83.40 & I \\
\hline L.D.C. & 1 & $2.80 \mathrm{ab}$ & I & 3.94 & I & 11.56 & I & 15.50 & I & $37.10 \mathrm{~b}$ & I & 47.40 & I & 84.50 & I \\
\hline
\end{tabular}

* values in each column marked with the same letter don't differ significantly between themselves

3. Calcomelanosols brownised; 4. Calcocambisols; 5. Terra rossa; P. M. - Parent material; M. L. - Massive limestone;

D. L. - Dolomitic limestone; B. L. - Bituminous limestone; P. L. - Plate limestone; D. M. - Dolomitic marbles;

L. D. C. - Laminated (plate) dolomite and calcite

The content of both fractions together (clay + silt) or physical clay in the Amo horizon amounts $55.19 \%$ in organomineral calcomelanosol, $59.87 \%$ in organogenic, while the highest content is found in the brownised calcomelanosols $63.48 \%$. The mean value of this fraction in cambic horizon (B)rz in brownised calcomelanosols amounts $67.36 \%$.

With regard to the subtypes in the Amo horizons, we can confirm that the fine sand and silt fractions are almost equally present in the organogenic and brownised calcomelanosols, the coarse sand fraction in the organomineral and brownised calcomelanosols, while the clay fraction is increasing, starting from the organogenic towards brownised calcomelanosol.

The presented data for the mechanical composition of calcomelanosols in our research are very similar to the results of $[9,10]$. In their research, they have obtained $41.00 \%$ for the physical sand fraction and $59.02 \%$ for the physical clay fraction.

In all profiles of calcocambisols, fine earth dominates over coarse fragments. The average coarse fragments content in the Amo horizon in these soils amounts to $4.82 \%$, and in the cambic horizon (B)rz it amounts to $1.65 \%$. In fine earth the physical clay fraction in both horizons, Amo and (B)rz, has double presence in relation to the physical sand fraction. The average content of the physi- cal sand fraction in the Amo horizon amounts to $33.43 \%$, and in the cambic horizon (B)rz it is $22.50 \%$, where the fine sand fraction dominates over the coarse sand fraction. Thus, in the Amo horizon there is on average $27.25 \%$ fine sand and $6.18 \%$ coarse sand, and in the (B)rz horizon there is $16.89 \%$ fine sand and $5.31 \%$ coarse sand. In the physical clay fraction, the content of the clay fraction is higher than the silt fraction. In the Amo horizon the average content of the clay fraction is $38.19 \%$, and in the cambic horizon (B)rz it amounts to $46.00 \%$, while the silt fraction in the Amo horizon amounts to $28.38 \%$ and in the cambic horizon (B)rz it amounts to $31.80 \%$. Such distribution of the mechanical composition is also a result of the remaining factors that have influence on the pedogenesis. Calcocambisols are formed on a lower height which dictates rise of temperature, and this contributes to the increase of clay content and the possibility for argilosynthesis. It is more than clear that in calcocambisols there is a texture differentiation. The ratio of the clay content between the cambic horizon (B)rz and the Amo horizon is $1.23: 1$. Such texture differentiation affects the differences in the physical, physical and mechanical and absorption properties between these two horizons.

According to $[9,10]$, the testings of the mechanical composition of calcocambisols, has deter- 
mined that the clay and silt fraction amounts to $70.06 \%$, and the coarse sand fraction amounts to $29.94 \%$. The data on the mechanical composition of the examined calcocambisols are similar to the data on this soil type which are also presented by other authors: $[11,12,13]$.

The researched terra rossa are characterized by lower mechanical composition heterogeneity, which is confirmed also with the lower number of texture classes. The coarse fragments content in these soils in the humus accumulative horizon Amo amounts to $3.18 \%$ and in the cambic horizon (B)rz it amounts to $1.42 \%$. If we compare the content of separate fractions in the terra rossa fine earth and those of calcocambisols it can be concluded that the ratio is similar, i.e. the physical clay fraction is present in higher percentage in relation to the physical sand fraction. Thus, in the Amo horizon the clay fraction dominates in the physical clay fraction, $43.08 \%$ on average, and $52.13 \%$ in the cambic horizon, and $24.90 \%$ in the Amo and $19.37 \%$ in the (B)rz horizon for the silt fraction. In the physical sand fraction, fine sand dominates with $23.75 \%$ in the Amo horizon and $19.45 \%$ in the cambic in relation to the content of coarse sand with $8.27 \%$ in the Amo horizon and $9.05 \%$ in the cambic horizon.
From the data on the mechanical composition provided by [2], we have observed that the physical clay fraction dominates with over $2 / 3$ in relation to other fractions. The clay content in the Amo horizon varies from 23.20 to $50.20 \%$, and in the cambic horizn (B)rz it amounts to $50.75 \%$ on average. The research of the soil profile of terra rossa on Galičica [14] have determined that the clay fraction content in the Amo horizon amounts to $42.10 \%$ and in the cambic horizon (B)rz it amounts to $69.40 \%$. It must be noted that our results on the average content of clay are completely approximate to the results of $[13,15,16,17,18,19]$. When it comes to the impact of the subsoil (limestone and dolomite) on the mechanical composition of the soil, care should be taken, because the soil is formed only from residual and it has the same mechanical composition in all locations on the same wall. The author [1] found at two locations of massive limestone that residual has 17.2 and $30.2 \%$ secondary phyllosilicates (clay). In Tables 3 and 4 profiles are grouped according to texture classes for each of the parent substrate for both horizons.

For horizon Amo it can be concluded that 6 stem parent materials all have 4 textural classes, 2 of them have 3 classes and 1 has two textural classes.

Table 3. Texture classes in horizon Amo in relation to parent material

\begin{tabular}{|c|c|c|c|c|c|c|c|}
\hline Parent material & $\begin{array}{c}\text { Total } \\
\text { number } \\
\text { of profiles }\end{array}$ & Loam & $\begin{array}{l}\text { Sandy } \\
\text { loam }\end{array}$ & $\begin{array}{c}\text { Sandy clay } \\
\text { loam }\end{array}$ & $\begin{array}{c}\text { Clayey } \\
\text { loam }\end{array}$ & Sandy clay & Clayey \\
\hline Massive limestone & 19 & 4 & - & 3 & 4 & - & 8 \\
\hline Dolomitic limestone & 7 & 1 & - & - & 4 & 1 & 1 \\
\hline Bituminous limestone & 7 & 1 & 1 & - & 5 & - & - \\
\hline Plate limestone & 8 & - & - & 3 & 5 & - & - \\
\hline Dolomitic marbles & 5 & - & 1 & 2 & 1 & 1 & - \\
\hline $\begin{array}{l}\text { Laminated (plate) } \\
\text { dolomiteand calcite }\end{array}$ & 6 & - & - & 3 & 1 & - & 2 \\
\hline
\end{tabular}

Table 4. Texture classes in horizon (B)rz in relation to parent material

\begin{tabular}{|c|c|c|c|c|c|c|c|}
\hline Parent material & $\begin{array}{c}\text { Total } \\
\text { number } \\
\text { of profiles }\end{array}$ & Loam & $\begin{array}{l}\text { Sandy } \\
\text { loam }\end{array}$ & $\begin{array}{c}\text { Sandy } \\
\text { clay loam }\end{array}$ & $\begin{array}{c}\text { Clayey } \\
\text { loam }\end{array}$ & $\begin{array}{l}\text { Sandy } \\
\text { clay }\end{array}$ & Clayey \\
\hline Massive limestone & 9 & - & - & - & 1 & - & 8 \\
\hline Dolomitic limestone & 4 & - & - & - & 1 & - & 3 \\
\hline Bituminous limestone & 3 & - & - & - & 1 & - & 2 \\
\hline Plate limestone & 5 & - & - & - & 4 & - & 1 \\
\hline Dolomitic marbles & 1 & - & - & - & - & - & 1 \\
\hline $\begin{array}{l}\text { Laminated (plate) } \\
\text { dolomite and calcite }\end{array}$ & 1 & - & - & - & - & - & 1 \\
\hline
\end{tabular}


From Table 4 it can be seen that the horizon (B)rz is found in a small number of profiles, in most clay it is in mechanical composition. The differences in mechanical composition and statistical justification of the above data can be best seen from the descriptive statistics and variance analysis made according to types, subtypes, horizons and parent material on which the soils are formed (Table 5) which is also the conclusion from our research.

Table 5. Analysis of variances of soil mechanical composition for the surface Amo and cambic horizon (B)rz

\begin{tabular}{|c|c|c|c|c|c|c|c|c|c|}
\hline \multirow[b]{2}{*}{ Hor. } & \multirow[b]{2}{*}{ Factors } & \multicolumn{8}{|c|}{ Mid-squares (Mean Sq) } \\
\hline & & Df & $\begin{array}{l}>2 \\
\mathbf{m m}\end{array}$ & $\begin{array}{c}0.2-2 \\
\mathrm{~mm}\end{array}$ & $\begin{array}{l}0.02-0.2 \\
\mathrm{~mm}\end{array}$ & $\begin{array}{c}0.02-2 \\
\mathrm{~mm}\end{array}$ & $\begin{array}{c}0.002-0.02 \\
\text { mm }\end{array}$ & $\begin{array}{c}<0.002 \\
\mathrm{~mm}\end{array}$ & $\begin{array}{c}<0.02 \\
\mathbf{m m}\end{array}$ \\
\hline \multirow{4}{*}{ Amo } & Soil types & 4 & $144.15^{* * *}$ & 106.49 & 258.48 & $355.85 *$ & $317.21 * * *$ & $418.90 * *$ & $355.85^{*}$ \\
\hline & Parent material & 5 & $95.56 * * *$ & 196.07 & $436.95^{*}$ & $478.22 * *$ & $329.02 * * *$ & 95.24 & $478.22 * *$ \\
\hline & $\begin{array}{l}\text { Soil type } \times \text { parent } \\
\text { material }\end{array}$ & 9 & 10.48 & 78.15 & 18.55 & 49.29 & 70.40 & 33.03 & 49.29 \\
\hline & Error & 33 & 16.85 & 109.47 & 130.15 & 105.43 & 39.49 & 75.04 & 105.43 \\
\hline \multirow{4}{*}{ (B) rz } & Soil types & 2 & $16.15 * * *$ & 63.43 & 54.97 & 233.05 & $363.99 * * *$ & $186.94 *$ & 233.05 \\
\hline & Parent material & 5 & $19.11 * * *$ & 20.04 & 49.15 & 74.76 & $78.52 *$ & 114.39 & 74.76 \\
\hline & $\begin{array}{l}\text { Soil type } \times \text { parent } \\
\text { material }\end{array}$ & 2 & $23.33 * * *$ & 48.01 & 9.73 & 72.56 & 5.88 & 55.38 & 72.56 \\
\hline & Error & 16 & 1.72 & 20.81 & 17.38 & 63.95 & 23.32 & 41.53 & 63.95 \\
\hline
\end{tabular}

* significant level $0.05 ; * *$ significant level $0.01 ; * * *$ significant level 0.001 .

\section{CONCLUSIONS}

The variance analysis has shown that in both horizons, the soil type has a significant effect on the variability of the coarse, silt and total clay content. In the humus accumulative horizon Amo, the soil type also has an effect on the physical sand fraction and the physical clay fraction. The parent material in both horizons affects the coarse and silt content variability, and in the Amo horizon it also affects the physical sand and physical clay content. In relation to the effect of the material (Table 5) it can be noted that in the Amo horizon there is the least coarse in the soils formed upon massive limestone $(5.79 \%)$ or value that statistically significantly differs from the soils formed upon dolomitic marbles and laminated (plate) dolomite and calcite (14.52 and $14.79 \%)$.

The effect of the remaining substrates does not significantly deviate in relation to the lowest and highest values on the content of this fraction. In the cambic horizon (B)rz, the lowest coarse content is present in massive limestone $(1.11 \%)$, in dolomitic limestone $(1.03 \%)$ and in bituminous limestone $(0.94 \%)$ which significantly statistically differ from dolomitic marbles $(8.15 \%)$ and plate limestone $(4.79 \%)$.

There is no statistically significant difference in the effect of the substrates on the coarse sand fraction, but there is a difference for the fine sand fraction. This fraction is the least present in the
Amo horizon in soils formed upon massive limestone $28.41 \%$ and dolomitic limestone $23.79 \%$, compared to dolomitic marbles $49.39 \%$. Unlike the Amo horizon, in the cambic horizon (B)rz there is no statistically significant difference for this fraction. The physical sand fraction has the lowest presence in the Amo horizon in soils formed upon dolomitic limestone $(28.71 \%)$, which statistically significantly differs from those formed upon dolomitic marbles which have the highest value for this fraction $(53.88 \%)$. Similarly as for the previous fraction, the physical sand fraction in the cambic horizon (B)rz also has no significant difference in relation to the substrates on which the soils have formed.

For the physical clay fraction (silt + clay) there is only a statistically significant difference in the silt fraction in both horizons. In the Amo horizon there is the smallest and approximate value in soils formed on dolomitic marbles $(15.86 \%)$ and laminated (plate) dolomite and calcite (15.93\%), and there is the highest average value in soils formed on bituminous limestone $(32.86 \%)$ and dolomitic limestone $(37.76 \%)$. The physical clay fraction has the lowest average value in soils formed upon dolomitic marbles (46.12\%) and the highest average value in soils formed upon dolomitic limestone $(71.29 \%)$. A lower statistically significant value is noted in soils formed upon massive limestone $(64.83 \%)$ and bituminous limestone $(62.06 \%)$. There is no statistically significant difference in the cambic horizon (B)rz for this fraction. 


\section{REFERENCE}

[1] M. Markoski: Genesis and properties of soil formed upon lime stones and dolomites in the Republic of Macedonia. Doctoral dissertation. Faculty of Agricultural Sciences and Food. Skopje. 2013, pp. 1-163.

[2] G. Filipovski: Soil of the Republic of Macedonia Vol III, Macedonian Academy of Sciences and Arts, Skopje. 1997, pp. 130-213.

[3] G. Filipovski, M. Ćirić: Terra rossa and other red soils. Soils of Yugoslavia. USDA NSF, Washington, DC and JDPZ Belgrade, 1969.

[4] T. Rakičević, R. Stojanov, M. Arsovski: Basic Geological Map 1:100,000 interpreter for the leaf Prilep. Federal Geological Institute, Belgrade, 1965.

[5] WRB: World Reference Base for Soil Resources, Diagnostic Horizons. Properties and Materials. Chapter 3. World Reference Base for Soil Resources, FAO, ISSS-AISS-IBG, IRSIC, Rome.

[6] J. Mitrikeski, T. Mitkova: Praktikum po pedologija. Zemjodelski fakultet, Skopje, 2006, pp. 1-164.

[7] H. Resulović: Metode istraživanja fizičkih svojstava zemljišta, knj. V. JDZPZ, Belgrade, 1971.

[8] R. Thurn, R. Herrmann, F. Kuickmann: Die Untersuchung von Boden. 3. Aufl. Neumann Verlag. Radebeuland, Berlin. 1955, pp. 1-271.

[9] M. Andreevski: Contains of humus of calcomelanosols and calcocambisols on the Jablanica Mountain. Master Degree Thesis, Faculty of Agriculture, Skopje, 1996, pp. 1-41.

[10] D. Mukaetov: Contains of exchangeable ions of calcomelanosols and calcocambisols on the Jabla- nica Mountain. Master Degree Thesis, Faculty of Agriculture, Skopje, 1996, pp.1-49.

[11] G. Antonović. V. V. Mrvić: Zemljište sliva Nišave. Institut za zemljište. Beograd. 2008, pp. 43-120.

[12] N. Pavićević: Tipovi zemljišta na Suvoj Planini. Zemljišta i biljka, god II. No.1. Belgrade. (1953), pp. 1-48.

[13] Ćorić. R: Adsorpciske značajke crveničnih tala na karbonatnim sedimentima. Sveučilište u Zagrebu. Agronomski fakultet, Zagreb, 2009, pp. 1-126.

[14] D. Mukaetov, D. Petkovski, M. Andreevski: Contents of exchangeable ions of calcocambisoil and terra rossa on the Galičica Mountain. Soils and Their Explanation. Proceedings. Macedonian Academy of Sciences and Arts, Skopje, 2000, pp. 83-93.

[15] J. Martinović: Tloznanstvo $i$ zaštita okoliša. Priručnik za inžinjere. Državna uprava za zaštitu okoliša, Zagreb, 1997, pp. 1-278.

[16] S. N. Koroxenidis, A. N. Polyzopoulos, S. G, Axaris, A study and classification of 25 representative soils in Northern Greece. Sci. Bull. Tessaloniki. No. 4. (1971).

[17] L. Marić: Terra rossa u karstu Jugoslavije. Jugoslavenska akademija znanosti i umjetnosti. Zagreb. Acta Geol. JAZU, 4 (1964), pp. 19-72.

[18] R. Delgado, J. M. Martín-Garicía, A. C. Oyonarte, G. Delgado: Genesis of the terrae rossae of the $\mathrm{Si}$ erra Gádor (Andalusia. Spain). Eur. J. Soil Sci. 54, (2003), pp. 1-16.

[19] G. Durn: Terra rossa in the Mediterranean region: Parent materials, composition and origin. Geol. Croat., Zagreb, 56/1 (2003), pp. 83-100.

\title{
МЕХАНИЧКИ СОСТАВ НА ПОЧВИТЕ ОБРАЗУВАНИ ВРЗ ВАРОВНИЦИ И ДОЛОМИТИ ВО РЕПУБЛИКА МАКЕДОНИЈА
}

\section{Миле Маркоски ${ }^{1}$, Татјана Миткова ${ }^{1}$, Коле Василевски $^{2}$, Зорица Томиќ $^{3}$, Марјан Андреевски $^{4}$, Вјекослав Танасковиќ ${ }^{1}$}

\author{
${ }^{1}$ Факултет за земјоделски науки и храна, Универзитет „Св. Кирил и Методиј“, Скопје, \\ Република Македонија \\ ${ }^{2}$ Шумарски факултет, Универзитет „Св. Кирил и Методиј“, Скопје, Република Македонија \\ ${ }^{3}$ Пољопривредни факултет, Универзитет во Белград, Република Србија \\ ${ }^{4}$ Земјоделски институт, Универзитет „Св. Кирил и Методиј“, Скопје, Република Македонија
}

Во овој труд се презентираат резултатите од истражувањето на влијанието на матичниот супстрат врз механичкиот состав кај калкомеланосолите, калкокамбисолите и црвениците. Содржината на одделни фракции на ситноземот на калкомеланосолите варира во зависност од поттипот. Фракцијата физички песок (крупен + ситен песок) во хоризонтот Ато изнесува 44,81\% во органоминералната варовничко-доломитна црница, $40,13 \%$ во органогената и $36,52 \%$ во браунизираната калкомеланосол. Во хоризонтот (B)rz кај браунизираните калкомеланосоли изнесува 32,64\%. Содржината на глина+прав, или физичка глина, во хоризонтот Ато изнесува 55,19\% кај органоминералните црници, 59,87\% кај органогените и највисока е во браунизираните калкомеланосоли - 63,48\%. Просечната вредност на оваа фракција во хоризонтот (B)rz кај 
браунизираните калкомеланосоли изнесува 67,36\%. Во калкокамбисолите просечната содржина на фракцијата физички песок во хоризон Ато изнесува 33,43\%, а во камбичниот хоризонт (B)rz 22,50\%. Кај црвеницата фракцијата физичка глина е застапена со поголем процент во однос на фракцијата физички песок. Во хоризонтот Аmо во фракцијата физичка глина доминира фракцијата на глина, средно 43,08\%, и во камбичниот хоризонт изнесува 52,13\%, фракцијата прав во хоризонтот Ато изнесува 24,90 \% и во хоризонтот (B)rz изнесува 19,37\%. Од истражувањето на почвите 36\% од почвите се формираат врз масивни варовници, $13 \%$ се формираат врз доломитски варовници и битуменски мермери, $16 \%$ врз плочести мермери, $10 \%$ врз доломитски мермери и $12 \%$ врз плочести доломити и калцит-доломитски мермери.

Клучни зборови: механички состав; матичен супстрат; какломеланосол; калкокамбисол; црвеница 